\title{
Detection of high potential areas of persian oak forests decline in Zagros, Iran, using topsis method
}

\author{
Mohammad Javad Moradi ${ }^{1 \mathrm{iD}}$, Hadi Kiadaliri ${ }^{1 * i \mathrm{D}}$, Sasan Babaie Kafaky ${ }^{1 \mathrm{iD}}$, Hossein Bakhoda ${ }^{1}$
}

${ }^{1}$ Islamic Azad University, Tehran, Iran

SILVICULTURE

\begin{abstract}
Background: During the past decade, the phenomenon of Oak decline has affected valuable Zagros Oak Forests in western Iran. Quercus brantiias the most important tree species of these forests has been damaged more than any other species. Many factors are involved in this phenomenon. The purpose of this study was to identify areas with high potential for decline and determine the most important factors affecting it. In this study, using multi-criteria evaluation methods based on the Geographic Information System (GIS) Technique for Order of Preference by Similarity to Ideal Solution (TOPSIS) method and fuzzy logic, the map of decline potential of two selected stands (Dalab and Cheghasabz) in llam Province was prepared to reveal the highrisk areas of decline. The analytical hierarchical process was used to determine the weight of the factors.
\end{abstract}

Results: The results showed that both selected stands had decline potential. However, the Dalab stand at $25 \%$ and the Cheghasabz, at approximately $60 \%$ of the stand has an extreme potential for decline. Rainfall factors, pests, and diseases also have the greatest effect on Oak forest decline.

Conclusion: Due to socio-economic problems such as land use change, fire, tourism, grazing, and pruning, the Cheghasabz is more prone to decline than the Dalab, which was a forest reserve. The multicriteria evaluation model used in the study can be a guide in identifying high-risk areas in other parts of the Zagros forests. The large area of critical areas in these two regions reveals the need for planning to implement support operations to reconstruct damaged ecosystems.

Keywords: Querqus brantii, Topsis, AHP, GIS-guided management, Conservation

\section{HIGHLIGHTS}

Making a map of the potential decline of two Oak forests (Dalab and Cheghasabz stands) in western Iran, with TOPSIS and fuzzy logic in GIS and determining the weight of Oak forest decline factors by AHP (analytic hierarchy process) method.

Rainfall factors, pests, charcoal disease, and land use change have the greatest impact on Oak forest decline. There was higher decline potential in Cheghasabz than Dalab due to more socio-economic problems. Areas with high decline potential were determined for management and conservation programs.

MORADI, M. J.; KIADALIRI, H.; KAFAKY, S. B.; BAKHODA, H. Detection of high potential areas of persian oak forests decline in Zagros, Iran, using topsis method. CERNE, v. 27, e-102640, doi: 10.1590/01047760202127012640 


\section{INTRODUCTION}

In recent years, disturbing reports have been provided of Oak decline in Zagros forests, suggesting that Oak forests in western provinces of Iran have been affected by this phenomenon (Amir Ahmadi et al., 2015; Zandebasiri and Pourhashemi, 2016; Goodarzi et al., 2016). Throughout the world, this disease has been found in many forests, in recent decades, and is known as "Oak silent death" (Pourhashemi et al., 2017; Hamzehpour et al., 2011). Its symptoms occur quickly and abruptly so that the Oak quickly dries up over a few months or the disease spreads rapidly throughout the healthy trees and can significantly damage its habitats (Zandebasiri et al., 2017; Hosseini, 2014).

Iran is located in the arid and semi-arid climate belt of the world with only $7.4 \%$ area containing forests (Keenan et al., 2015). The Zagros vegetation zone covers about 20 percent of Iranian soil in the west of the country (Karami et al., 2017). Some references cite Zagros forests to be 5,500 years old (MarvieMohadjer, 2012; Ahmadi et al., 2014). The area is referenced as a strategic ecosystem for a variety of socio-economic and biological reasons, and valuable environmental services (Mahdavi et al., 2015; Ghadirian et al., 2018).

In recent years, these forests have been heavily drained due to environmental stresses such as reduced rainfall, rising temperatures, drought, soil erosion, fire, dust, human impact, and pests that pose a serious threat to the future of the area (Hosseini et al., 2012; Amir Ahmadi et al., 2015). Deforestation of these forests has irreversible consequences, including reduction in forest canopy, soil erosion and biodiversity, disruption of ecological balance, villager migration, and desertification expansion (Kooh Soltani et al., 2018; Ghadirian et al., 2018). However, evaluation of the decline is still in its preliminary phase and no comprehensive study has been conducted on the exact causes. To date, various studies found to be effective have been conducted on this problem in different parts of Iran and around the world.

Many of these studies have divided the complex factors of Oak forest decline into several predisposing, inciting, and participant categories (Pourhashemi et al., 2017; Zandebasiri et al., 2017; Fan et al., 2012; Wang et al., 2012). In some studies, these factors are divided in two categories; namely, biological (pests and diseases) and nonbiological (climatic elements, soil characteristics) factors (Linares et al., 2011; Hosseini et al., 2017; Kabrick et al., 2008). In other words, several factors have contributed to the decline of Zagros Oak forests in Iran over the years, including climate factors (reduced rainfall, increased temperature, and duration of dry season) (Attarod et al., 2017). However, some other reasons, such as human interference, have also provided grounds for the decline of these trees (Hosseinzadeh, and Pourhashemi, 2015). These factors weaken the ecosystem and Oak trees (Pourhashemi et al., 2017). After the trees are weakened, other factors trigger and initiate this phenomenon. As a result, what causes the death of trees is the result of a combination of these factors. The combination, with different weight and share, determines the deteriorating conditions of Oak forest stands in Iran (Attarod et al., 2017; Hosseini, 2012; Karami et al., 2017; Ghadirian et al., 2018; Kooh Soltani et al., 2018).

It is not possible to easily identify these factors and map them to find locations with high decline potential, due to the remote availability and extension of the area by surveying and field operations. This requires the use of up-to-date methods. Preparing a decline potential map can help identify potential areas of decline and prevent increase of this devastating trend (Karami et al., 2017). Studies in this field have been conducted in Iran using logistic regression and neural network methods. The use of Multi Criteria Decision Making (MCDM) methods are considered in this study due to the high capability in providing a suitable solution for locating and identifying areas of potential decline (Mahdavi et al., 2015; Ghadirian et al., 2018). Today, with the development of new techniques and different models for zoning using RS and GIS methods, valuable studies have been conducted in different fields of natural resources. However, there has been neither empirical study on the definitive causes of decline by these methods nor preparation of potential decline maps. Studies have been undertaken by Kabrick et al. (2008) in the US, Gentilesca et al. (2017) in the Mediterranean, and Linares et al. (2011) in Morocco on the decline of Oak forests and their causes. However, few studies have investigated the causes of decline using multi-criteria evaluation methods. Among the few studies in this field is the study by Kooh Soltani et al. (2018) in Lorestan Province, using hierarchical analytical and fuzzy analysis to map the risk zones of Zagros Oak forests. For this purpose, they used slope, aspect, elevation, temperature and precipitation, dust, and soil factors as effective criteria for measuring decline. The weight of each criterion was calculated according to expert opinion, and the AHP method and fuzzy criteria maps were prepared using linear, increasing, and decreasing fuzzy membership functions (Gussian). In the present study, overlapping layers were used to map areas susceptible to Oak forest decline. The study results showed that southern and western areas were susceptible to severe deforestation with increasing altitude, reducing soil depth, increasing temperature and reduction of rainfall. Fuzzy operator 0.7 was the most accurate in measuring these factors.

In another study, Ahmadi et al. (2014) in Ilam Province, based on the AHP model, zoned climate, topographic variables, distance from roads and residential areas, and land cover to war zones were accessed on their susceptibility to decline. The results showed that climatic factors including mean annual rainfall, temperature, evaporation, and moisture had the highest score in the decline of the Persian Oak in the area; more than $36.7 \%$ of total area was at high-risk, and more than $51 \%$ of the area was at medium risk.

Unfortunately, reports have shown that large parts of Zagros Oak forests in Ilam Province in western Iran have been experiencing oak trees decline in recent years. Hence, in the present study, a map of Oak forest decline potential was developed using the geographic Information system (GIS) tool and fuzzy logic, and TOPSIS methods, which determined the most important criteria affecting this phenomenon by the analytical hierarchy process (AHP) method. 


\section{MATERIAL AND METHODS}

\section{Study area}

The present study has been conducted in two forest stands with signs of Oak decline called Cheghasabz and Dalab in Ilam Province, western Iran (Fig. 1 and Tab. 1). These areas were selected after initial information, visitation, and consultation with experts from the Ilam Department of Natural Resources and Watershed Management. In general, the climate of the area is mild to moderately humid (Mediterranean) with mild, humid winters and summers, not too hot, but arid (General meteorological office of llam Province). According to recorded statistics of the llam Synoptic Station, absolute maximum temperature is $40.6{ }^{\circ} \mathrm{C}$, absolute minimum temperature is $-12.6{ }^{\circ} \mathrm{C}$, and the mean annual rainfall is $350 \mathrm{~mm}$. The soil of the area is classified as Lithosols and Calcaric Regosols soils (Mahdavi et al., 2019). The forests in the area are mainly Persian Oak (Quercus brantii) in the form of seeding forest, and in some parts seeding and coppice forest. However, Pistacia atlantica, Acer cinerascens, Cratagus azarolus and Cerasus microcarpa species are also present with the Oaks. Although the phenomenon of decline is not limited to other species, this study focuses solely on Oak tree drying (Ilam Department of Natural Resources and Watershed Management Report, 2013).

\section{Weighting the factors}

The flowchart of the research method is described in Fig. 2. In this study, the primary target factors were identified using library studies, field visits and opinions of forest experts. Given that factors affecting the decline of these Oak forests were not identified and no suitable criterion was available, the AHP method was used to investigate the causes affecting Oak decline in order to determine their effect on the decline. The stages of implementing the research method in this section are as follows: 1.1 Categorization of the above factors in the form of questionnaires and distribute between experts and locals obtaining mean scores given for each cause. At this stage, 14 final factors were selected (Tab. 2). 1.2 Weighing the factors using AHP method and AHP online calculator software. The basis of this method of decisionmaking is pairwise comparisons and the creation of hierarchical trees (Zandebasiri and Pourhashemi, 2016; Saaty, 1990). Applying this method requires the following steps (Muhammadi et al., 2015): First: Define the problem at hand, introduce all the objectives of the problem, and set effective criteria. Second: Create factor structure by the Hierarchical Analytical Process and form a decision diagram. Third: Form pairwise comparison matrix. Fourth: Extract the coefficients of matrix significance and weight of the factors. The method of determining the weight of the factors is a pairwise comparison based on preference judgments values 1 to 9 and the Saaty Table (Saaty, 1990). Fifth: Pairwise comparisons matrix compatibility test. Saaty (1990) provided this stage known as the Consistency Ratio (CR). The acceptable CR ratio for matrix $A$ should be less than 0.1 . Sixth: Determine the rating or relative significance of decision

Tab. 1 Characteristics of studied forest stands (Chegasabz and Dalab) in Ilam Province, western Iran.

\begin{tabular}{|c|c|c|c|c|c|c|}
\hline Region & Distance to Ilam (km) & Slop & Elevation (m) & Location Coordinate & Area (ha) & Forest type \\
\hline Chegasabz & 3.15 & 16.6 & 1560 & $33^{\circ} 42^{\prime} 03^{\prime \prime} \mathrm{N} 46^{\circ} 23^{\prime} 00^{\prime \prime} \mathrm{E}$ & 2771 & Pure Oak \\
\hline Dalab & Dalab & Dalab & 1834 & $33^{\circ} 36^{\prime} 33^{\prime \prime} \mathrm{N} 46^{\circ} 29^{\prime} 49^{\prime \prime} \mathrm{E}$ & 2945 & Pure Oak \\
\hline
\end{tabular}
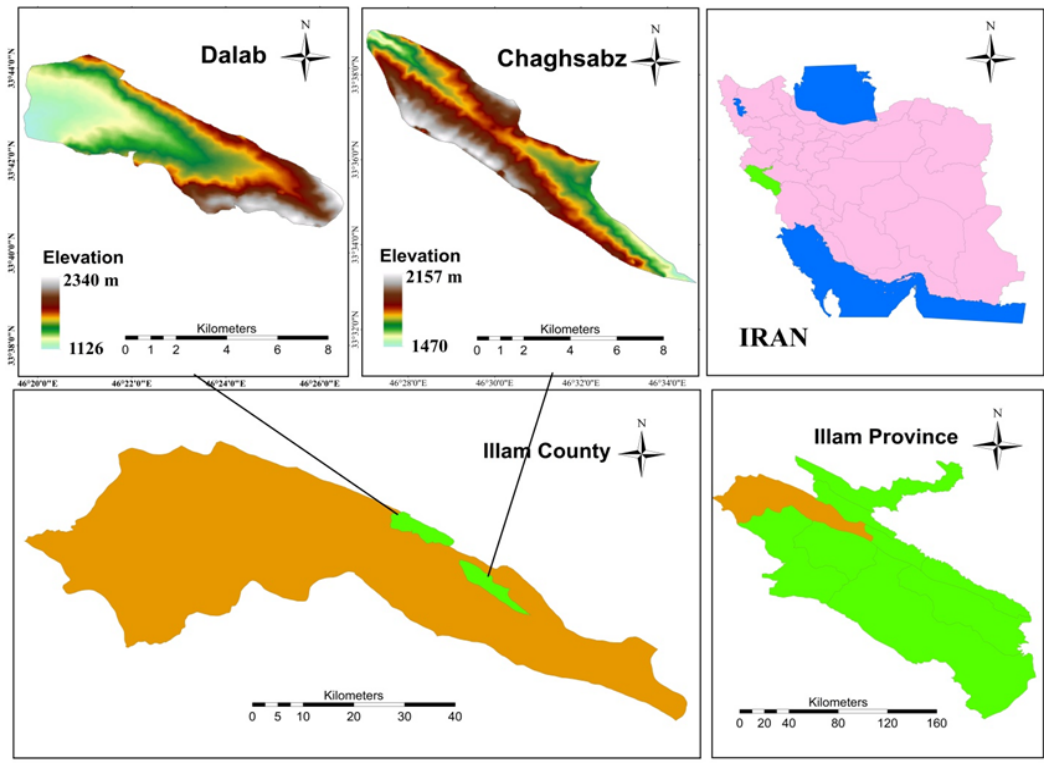

Fig. 1 Location of selected forest stands (Chegasabz and Dalab) in Ilam Province, western Iran. 


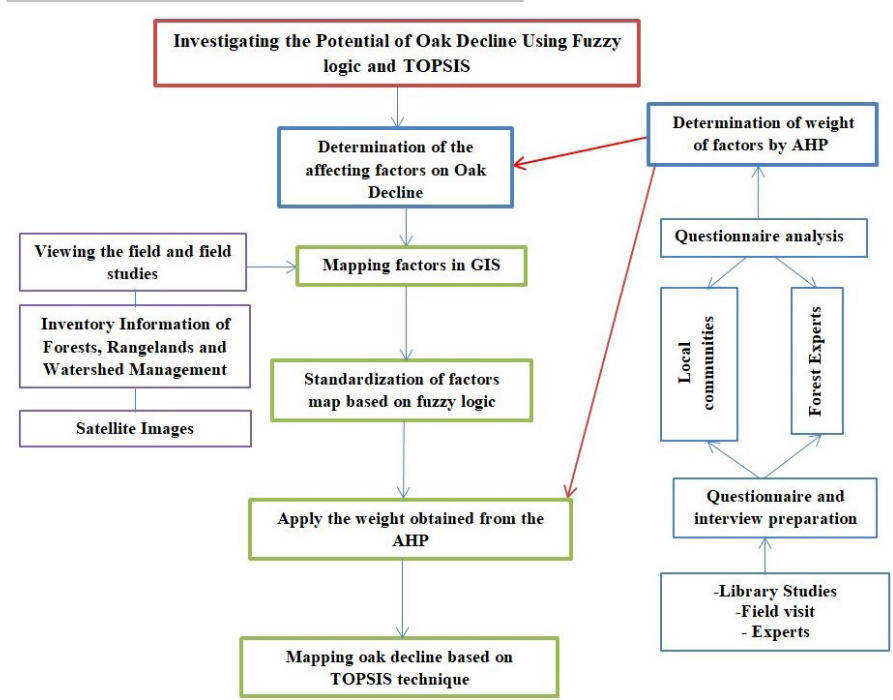

Fig. 2 Flowchart of Research Method.

Tab. 2 Weight of factors affecting Oak forest decline obtained from AHP method.

\begin{tabular}{cccc}
\hline Factor & Weight & Factor & Weight \\
\hline Annual Rainfall Pests & 0.149 & Tourism & 0.052 \\
Pests & 0.138 & Fire & 0.050 \\
Charcoal disease & 0.131 & Slop & 0.045 \\
Land use change & 0.115 & Annual Temperature & 0.030 \\
Pruning & 0.093 & Elevation & 0.027 \\
Grazing & 0.079 & Canopy density & 0.020 \\
Aspect & 0.061 & Diameter at breast height & 0.010 \\
\hline
\end{tabular}

options ranking them in relation to the criteria and purpose based on scores obtained.

\section{Prepare factors map}

After determining the weight of the factors, the basic map was prepared. Prepare physiographic factor map (slope, elevation, and aspect) based on digital elevation model (DEM). Prepare climatic factor map (mean annual rainfall and temperature) using statistical information of synoptic stations and rain gauges of Iran Meteorological Organization. Prepare land use change map using field views and matching Google Earth image. Prepare pest and charcoal disease map using Ilam General Department of Natural Resources and Watershed Management data and field visits. The pests identified in the area belong to the families Cerambycidae and Buprestidae and charcoal disease (Biscogniaxia mediterraneum). Prepare a map of pruning, fire, livestock grazing, and tourism using field visits and interviews with experts and locals. Prepare silvicultural factor map (diameter at breast diameter and canopy density) based on Ilam General Department of Natural Resources and Watershed Management (2013).

\section{Prepare standardized factor map}

The fuzzy logic method (Zadeh, 1965) is generally used for the standardization of criteria (Kooh Soltani et al., 2018). In this method, all values of the basic map layers are in a range between 0 and 1 (Zadeh, 1965). The standardization process in the fuzzy method is implemented by formatting values into a membership set. Factor map fuzzification was performed using logic in GIS. Higher values of fuzzy membership function indicate higher forest decline potential.

\section{Prepare the final map of the decline potential using TOPSIS method}

The TOPSIS model was proposed by Hwang and Yoon (1981) (Hwang and Yoon, 1981). In this method, ' $m$ ' option is evaluated by ' $n$ ' index. It is assumed that the utility of each index is uniformly increasing or decreasing, which is defined as the ideal positive $\left(A^{+}\right)$and ideal negative $\left(A^{-}\right)$. The technique is based on the notion that the chosen option should have the least distance to the ideal positive solution and the maximum distance to the ideal negative solution (Ertugrul and Karakasoglu, 2007).

\section{Modeling steps by TOPSIS method}

In this study, the TOPSIS model was implemented in eight steps, respectively, as follows (Mohammadi et al., 2015): First: Form decision matrix using data collected and a data matrix based on ' $n$ ' index and ' $m$ ' option. Second: Nonscale decision matrix. Third: Determine weight of each index. Fourth: Convert decision matrix in step 2 into a non-scalar weighted matrix. Fifth: Find the ideal positive solution $\left(A^{+}\right)$ by determining maximum value and ideal negative solution $\left(A^{-}\right)$by determining minimum value. Sixth: Calculate distance from ideal positive to ideal negative based on Euclidean method. Seventh: Calculate relative proximity of each option with the ideal solution. Eighth: Rank options based on their proximity to ideal solution. The final output is a spectral map in which the spectral values represent the rate of decline potential for the study area classified into four classes (low, moderate, high and extreme decline).

\section{Modeling steps by TOPSIS method}

To check the accuracy of the prepared decline potential map, field visits were made to areas with high and 
extreme decline classes. To determine the degree of decline and drought, the health status of Oak in four categories was evaluated based on the percentage of canopy decline and observation of appearance at the location of random points in the field. Healthy trees without signs of the effects of drought, pests, and diseases on the trunk and canopy were examined. Those trees with weak decline (tops of branches or part of the crown are less than $25 \%$ dry), moderate decline (part of the crown is 25 to 50 percent dry), and severe decline (most of the main branches are dry and in total more than $50 \%$ of the crown is dry) were examined as well (Hosseinzadeh and Pourhashemi, 2015).

\section{RESULTS}

\section{Factors affecting Oak forest decline}

In this study, 14 final factors (climatic, physiographic, silviculture, and socioeconomic) were selected based on accumulated studies. Thereafter, relative weight and the coefficient of significance of each cause were determined based on the views of both experts and groups of local communities and based on the AHP method (Tab. 2). The results showed that the factors of rainfall, pests, charcoal disease, and land use change had the highest weight and the silvicultural factor had the least effect on Oak forest decline in the study areas, respectively.

\section{Basic map and standardized map of factors affecting Oak forest decline}

The information obtained from the factors listed in the form of a database with the same geo-referencing system (UTM, WGS 1984, Zone 38 N) was converted to a digital format in software GIS and the basic factor map was prepared. In this paper, only maps of the highest weighted factors are given (Fig. 3 and 4). In the next stage, all factors were standardized based on fuzzy logic and membership functions in which higher membership values indicate higher utility and lower membership values indicate lower utility for the given objective.

\section{Prepare Oak forest decline prone area map by TOPSIS method}

The map of Oak forest decline potential classes in the two studied stands was classified according to the mentioned method as low, moderate, high, and extreme classes (Fig. 5). The class area is shown in Fig. 6. The results showed that in the Dalab species 282.946 hectares had extreme decline potential, 455.51 hectares had high decline potential, 1635.57 hectares had moderate decline potential, and 571.30 hectares had low decline potential. In the Cheghasabz species, 619.9691 hectares had extreme decline potential, 1042.13 hectares had high decline potential, 701.87 hectares had moderate decline potential, and 406.84 hectares had low decline potential. In the Cheghasabz 59.98\%, and in the Dalab $25.06 \%$ of the area had extreme decline potential. At a glance, the Cheghasabz species had the worse condition in terms of decline.

\section{Validation of final maps}

In order to verify the maps obtained from field visits, the area and ground control in the damaged decline classes with high and extreme decline was used. The coordinates of the study points and photos of the areas are presented in Tab. 3 and Fig. 7.

Tab. 3 Field validation matrix of Oak forest decline category.

\begin{tabular}{cc}
\hline Stand & Coordinates of points \\
\hline Dalab & $33^{\circ} 43^{\prime} 35^{\prime \prime} N 46^{\circ} 21^{\prime} 28^{\prime \prime} \mathrm{E}$ \\
& $33^{\circ} 42^{\prime} 56^{\prime \prime} N 46^{\circ} 22^{\prime} 23^{\prime \prime} \mathrm{E}$ \\
& $33^{\circ} 42^{\prime} 07^{\prime \prime} N 46^{\circ} 22^{\prime} 50^{\prime \prime} \mathrm{E}$ \\
\hline & $32^{\circ} 38^{\prime} 39^{\prime \prime} N 46^{\circ} 27^{\prime} 38^{\prime \prime} \mathrm{E}$ \\
& $33^{\circ} 37^{\prime} 29^{\prime \prime} N 46^{\circ} 28^{\prime} 46^{\prime \prime} \mathrm{E}$ \\
Cheghasabz & $33^{\circ} 36^{\prime} 26^{\prime \prime} N 46^{\circ} 33^{\prime} 07^{\prime \prime} \mathrm{E}$ \\
& $33^{\circ} 35^{\prime} 03^{\prime \prime} N 46^{\circ} 31^{\prime} 32^{\prime \prime} \mathrm{E}$ \\
& $33^{\circ} 34^{\prime} 02^{\prime \prime} N 46^{\circ} 32^{\prime} 53^{\prime \prime} \mathrm{E}$ \\
\hline
\end{tabular}

\section{DISCUSSION}

Analysis of factors in this study, using the AHP method, showed that the factors of rainfall, pests, charcoal disease and land use change had the highest weight. As shown, the most prominent role is played by socioeconomic reasons (38.9\%), pests and diseases (26.9\%), indicating the important role of these causes in the susceptibility of Oak forest decline. The study results by Ahmadi et al. (2014) in the same province based on this model and on climatic and topographic variables, distance from roads and residential areas, and vegetation, showed that climatic factors, including annual rainfall played the greatest role in the decline of Persian Oak forests. This shows annual rainfall to be the most influential factor, which was understood in the present study. Kooh Soltani et al. (2018) investigated the potential of Oak forest decline in Lorestan Province, Iran, using a fuzzy analytical hierarchical process. They incorporated a set of topographic, climatic, dust, and soil factors in the map of decline-prone areas. The results of this study also evaluated rainfall, temperature, and soil as the most important factors. A study by Ghadirian et al. (2018) showed that drought index was the most important and effective factor compared to socioeconomic factors on identifying forested areas with critical conditions.

The significance of this study is the consideration of more factors, especially pest, disease, and socioeconomic causes of the decline such as land use change, grazing, pruning, tourism, and fire-fallow cultivation taking into account local conditions. Other studies have used fewer and different numbers of factors (Ghadirian et al., 2018; Ahmadi et al., 2014; Kooh Soltani et al., 2018). In general, lower altitudes, for more access, higher slopes, due to lower soil depth and erosion, and southern and western aspects, due to more drought and heat, and areas with lower rainfall and higher temperature, the presence of pests and diseases, and the presence of socioeconomic problems all have higher degrees of Oak forest decline.

llam Province is one of the provinces in western Iran that has been experiencing drought in recent years 


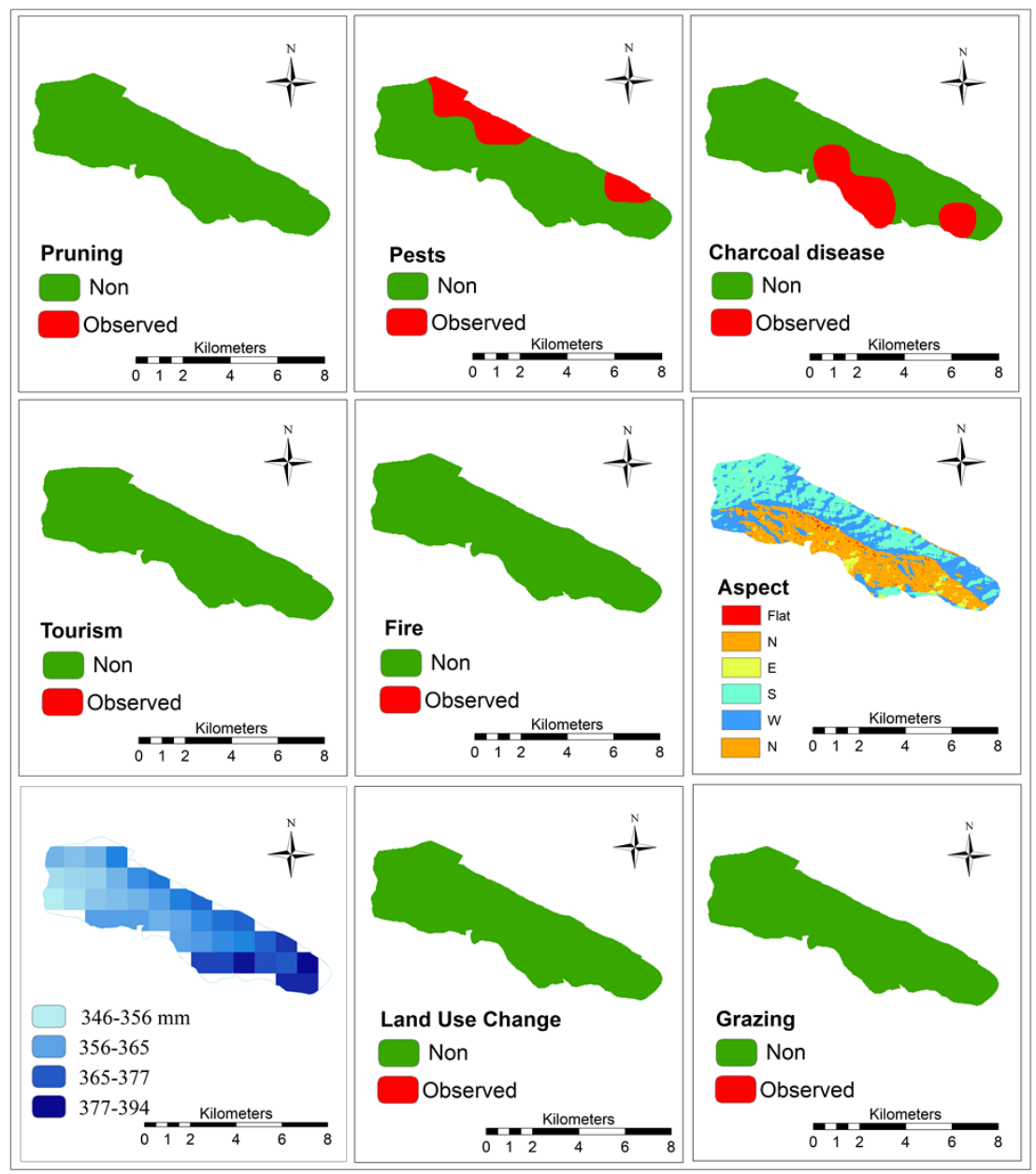

Fig. 3 Basic maps of factors in Dalab stands.

(Hosseini et al., 2017). Drought stress can weaken the trees and their physiological properties and make them susceptible to pathogens such as fungi and pests (Attarod et al., 2017; Pourhashemi et al., 2017). The opportunistic nature of charcoal disease as well as wood and borer insects has infected more trees in the area. In Zagros forests, wood beetles have emerged after recent droughts, following drought, and physiological tree weakness, causing an acceleration in the mortality rate of drought-susceptible trees (Goodarzi et al., 2016). These results are in accordance with the results of the Hosseini (2012) study on the conditions of Oak forest decline habitats with the presence of borer beetles. In this study, the presence of these factors in areas with higher potential for decline is evident in the final map. Studies by Jenkins and Pallardy (1995) in Ozark forests in Missouri, USA, have reported drought and the prevalence of Armillaria root rot as major causes of red oak trees death.

The life and livelihood of many people in this area of western Iran depend on these forests due to the large expanse of these forests. Therefore, some factors such as human interference have paved the way for the decline of these trees in various forms. Land use change, increasing levels of agricultural land, livestock entry and grazing, increase in the arrival of tourists, and as the course of decline has increased the lack of proper protection has provided the grounds and conditions necessary to exacerbate this Oak forest decline (Hamzehpour et al., 2011; Zandebasiri and Pourhashemi, 2016; Pourhashemi et al., 2017). The present study showed that a number of different factors have played a role in the decline of Oak trees in the area, which is difficult to fully understand due to the longterm functioning of these factors in forest ecosystems and many other interferences. Therefore, the management of this environmental problem should take into account the effects of all primary and secondary causes, both directly and indirectly (Hamzehpour et al., 2011; Zandebasiri and Pourhashemi, 2016; Pourhashemi et al., 2017; Hosseini, 2014; Hosseini, 2012). Most pests and diseases penetrate trees through wounds in the trees. Cutting and pruning, fire, damage due to livestock grazing and agriculture on the forest floor, all cause damage to roots and soil compaction. These issues, while destroying forests and cause soil erosion, weaken the trees and reduce their resistance to pests and diseases (Hamzehpour et al., 2011). Aber et al. (2002) also consider human activities as the intensifiers of the effects of natural and environmental events.

The map of Oak forest decline potential shows that the total forests of the two stands have decline potential. The area with higher degrees of decline is lower in the Dalab stand and higher in the Cheghasabz stand, so that in the 


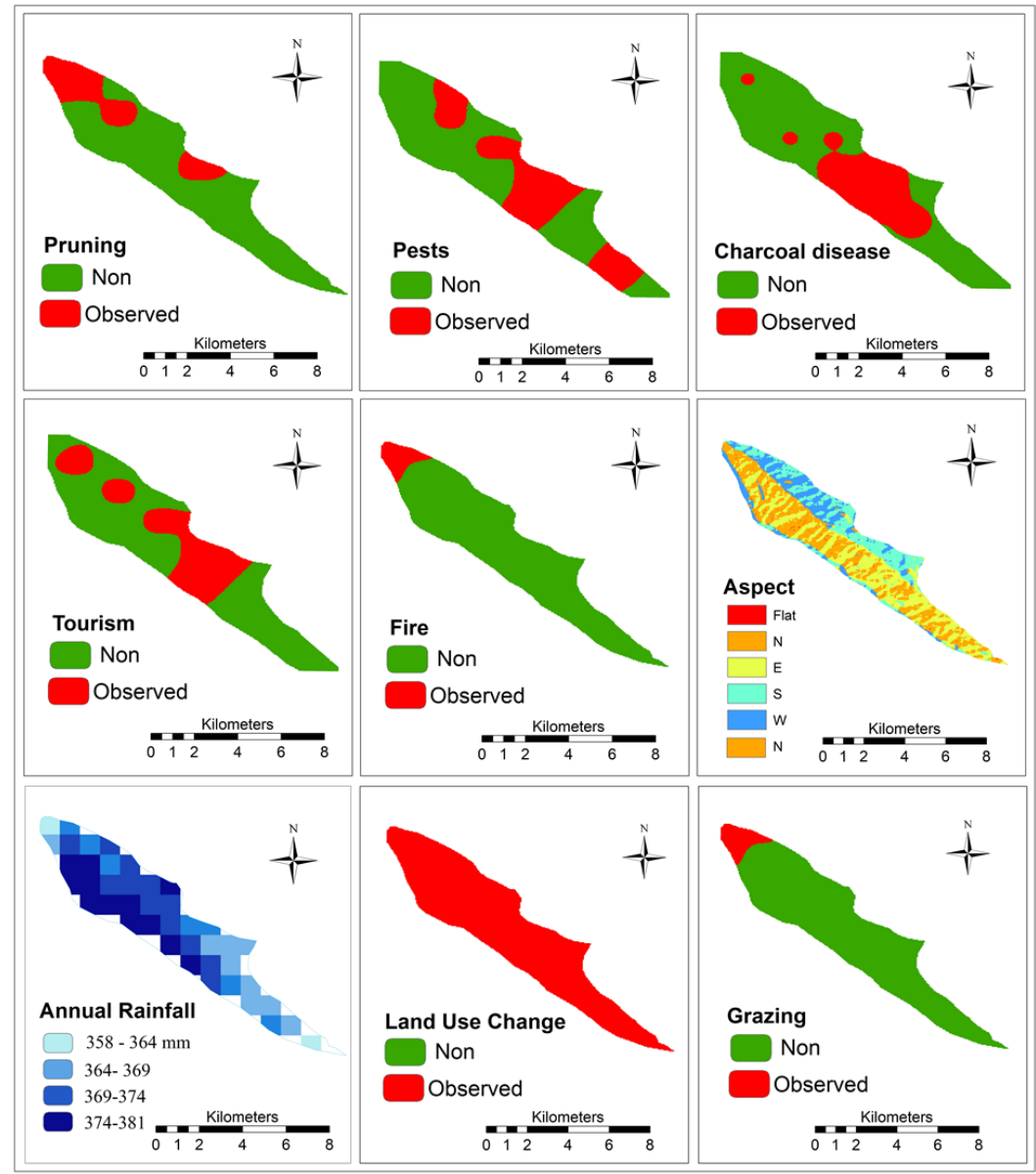

Fig. 4 Basic maps of factors in Cheghasabz stands.
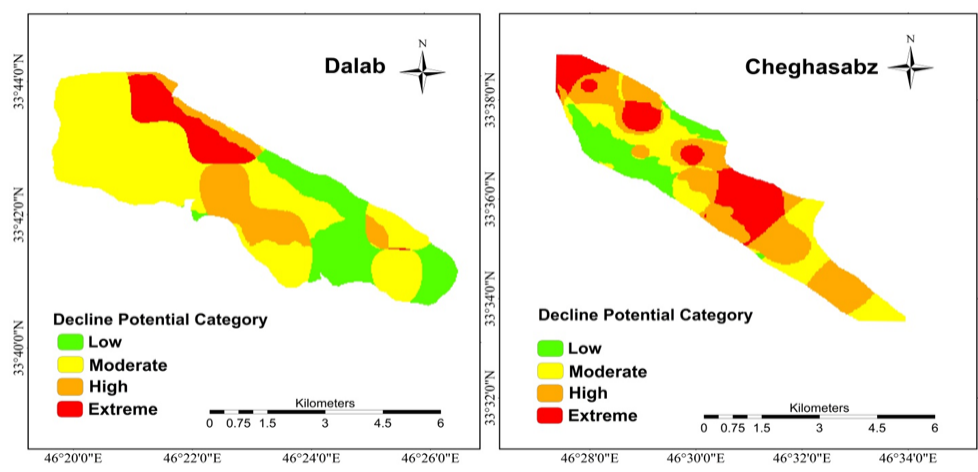

Fig. 5 Classification map of Oak decline potential in the study areas.

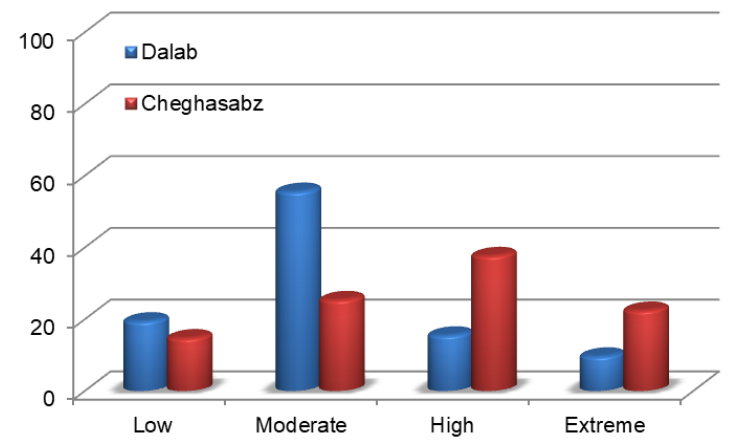

Fig. 6 Area of Oak decline potential in the study areas by TOPSIS method. 

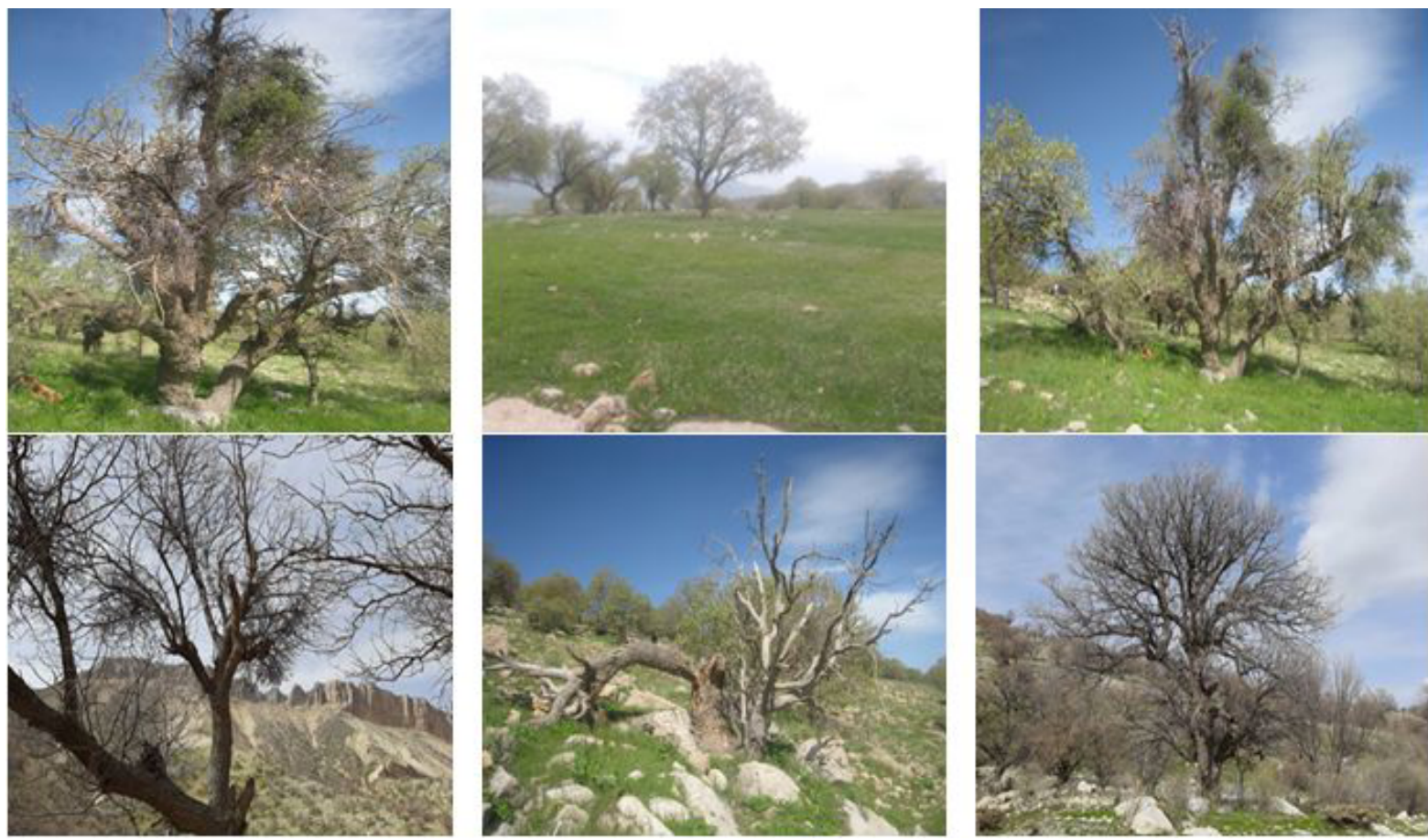

Fig. 7 Images of validation points in study areas (top: Dalab; bottom: Cheghasabz).

Dalab stand, $25 \%$ of the total stand has high and very high decline potential. This area is about $60 \%$ in the Cheghasabz stand. The Dalab stand has been a forest reserve for 10 years Thus, we are less likely to see the effects of socioeconomic factors such as fire, tourism, livestock grazing, pruning, and land use change on the area. The Cheghasabz stand has greater economic and social problems and the presence of tourists, other villagers and their livestock, due to greater access and proximity to urban and rural population centers, and consequently fires, have been observed there.

Studies of Ahmadi et al. (2014) and Kooh Soltan et al. (2018) have also used multi-criteria evaluation methods, AHP and WLC, and the fuzzy analytical hierarchy process (AHP) methods, respectively. AHP is one of the most efficient decision-making methods that is based on pairwise comparisons, and allows managers to examine different scenarios. This process is a set of judgments and evaluations performed in a logical way (Saaty, 1990). The results obtained from previous studies show that the AHP method has a favorable application with respect to simplicity, flexibility, and the use of qualitative and quantitative criteria at the same time as well as the ability to examine the consistency of judgments related to location (Kooh Soltani et al., 2018; Ahmadi et al., 2014). The results of this study showed the applicability of methods such as AHP and TOPSIS due to the nature of their interactions and various criteria used in the study. This method has greater power and many advantages due to more simplicity and flexibility, than other methods, and has the ability to overlap with GIS (Muhammadi et al., 2015). Therefore, the production of decline potential maps based on the model used can be suggested as a method to identify high-risk and crisis areas for other areas of these forests. The large area of critical areas in this study reveals the need for planning, as the first step, to identify affected areas and implement conservation, support, and rehabilitation operations to rebuild damaged ecosystems and help to regenerate the said areas.

Below are practical suggestions: Need for planning in order to take more protective, stringent operations as the first solution. Provide decline potential maps, based on the model, as a method to identify high-risk and crisis areas for other areas of these forests. Perform various forestry operations such as large canopy pruning to reduce competition, reforestation, and management of stand composition towards species with more adaptation to drought, in addition to watershed management operations such as wastewater management and water storage. Development of identification programs for pests, diseases, and the perfect conservation of these areas in order to prevent or limit any kind of exploitation and mechanical control in the field. Help to reduce human pressures, control of grazing, and changes in land use, especially in critical areas, by developing multi-purpose forestry programs in local communities such as multi-use projects through workshops, and gradual replacement of fossil fuels with clean energy.

\section{CONCLUSION}

The decline of the Zagros Oak forest ecosystem is a multidimensional and complex phenomenon. The variety of factors affecting this phenomenon in different regions has made it very difficult to judge and plan for it. In this study, some factors affecting this phenomenon in western Iran in the Dalab and Cheghasabz stands in Ilam Province were studied by the AHP method. Overall results showed that rainfall, pests, diseases, and land use changes are the most 
current reasons causing an effect on this phenomenon. fuzzy logic and the TOPSIS methods were used to construct the potential zoning map. The level of high-risk areas in Cheghasabz is higher due to the greater effects of socioeconomic factors. Taking into consideration that all levels of two-stands forests have decline potential, the map of Oak forest decline potential, based on the model used in this study, can be used as a guide in identifying high-risk areas and applying protective conservation management in these areas. It is suggested that similar studies be undertaken in other parts of these forests based on the model used, in which other factors such as soil type and depth, amount of organic matter and soil moisture, and other ecological factors such as competition in Oak decline research be considered. The use of remote sensing technology and time-series satellite data to detect and evaluate forest changes can also play a key role in understanding the causes of Oak forest decline.

\section{ACKNOWLEDGMENTS}

We are grateful all experts and Engineers in Natural resources and watershed management department of Ilam province, Iran for their help with gathering information. Also thanking to the reviewers and the editors for their comments and suggestions.

\section{AUTHORSHIP CONTRIBUTION}

\author{
Project Idea: MJM and HK \\ Database: MJM \\ Processing: SBK and HB \\ Analysis: MJM, SBK and HB \\ Writing: MJM and HK \\ Review: HK, SBK and HB.
}

\section{REFERENCES}

ABER, J. S.; WALLACE, J.; NOWAK, M. C. Response of forest to climatic events and human management at Fort Leavenworth, Kansas Geological Survey. Current Research in Earth Sciences, Bulletin 248, part 1, 2002.

AHMADI, R.; KIADALIRI, H.; MATAJI, A.; KAFAKI, S. Oak forest decline zonation using AHP model and GIS technique in Zagros forests of llam province Journal of Biodiversity and Environmental Sciences, v. 4, n. 3, p.141-150, 2014.

AMIR AHMADI, B.; ZOLFAGHARI, R.; MIRZAEI, M. R. Relation between Dieback of Quercus brantii Lindl. Trees with Ecological and Sylvicultural Factors, (Study Area: Dena Protected Area). Ecology of Iranian Forests, v. 3, n. 6, p. 19-27, 2015. (In Persian) http://ifej.sanru.ac.ir/article-1-193-en.html

ATTAROD, P. SADEGHI S. M. M. PYKER, T. G.; BAYRAMZADE, V. Oak treesdecline; a sign of climate variability impacts in the west of Iran. Caspian Journal of Environmental Sciences, v. 15, n. 4, p. 373-384, 2017.

ERTUGRUL, I.; KARAKASOGLU, N. Performance evaluation of Turkish cement firms with fuzzy analytic hierarchy process and TOPSIS methods. Journal of Expert Systems with Applications, v. 36, p. 702-715. 2007.

FAN, Z.; FAN, X.; CROSBY, M. K.; MOSER, W. K.; HE, H.; SPETICH, M. A.; SHIFLEY, S. R. Spatio-temporal trends of oak decline and mortality under periodic regional drought in the Ozark Highlands of Arkansas and Missouri. Forests, v. 3, n. 3, p. 614-631, 2012.

GENERAL METEOROLOGICAL OFFICE OF ILAM PROVINCE. Available at: http://www.ilammet.ir/
GENTILESCA, T.; CAMARERO, J. J.; COLANGELO, M.; NOLE, A.; RIPULLONE, F. Drought-induced oak decline in the western Mediterranean region: an overview on current evidences, mechanisms and management options to improve forest resilience. iForest-Biogeosciences and Forestry, v. 10, n. 5, p. 796. 2017.

GHADIRIAN, O.; HEMAMI, M. R.; SOFFIANIAN, A.; POURMANAFI, S.; MALEKIAN, M. The Zoning of Lorestan Province's forests decline risk using logistic regression model. Journal of Animal Environment, v. 10, n. 3, p. 495502, 2018. (In Persian) http://www.aejournal.ir/article 85032.html

GOODARZI, N.; ZARGARAN, M. R.; BANJ SHAFEIEI, A.; TAVAKOLI, M. The effect of geographical directions and location on dispersion of Oak decline, Shurab forest area, Lorestan Province, Iran. Forest Research and Development, v. 23, n. 3, p. 273-287,2016. (In Persian) https://www.sid.ir/en/ journal/ViewPaper.aspx?id=571215

HAMZEPOUR, M.; KIADALIRI, H.; BORDBAR, K. Preliminary study of manna oak (Quercus brantii Lindl.) tree decline in Dashte-Barm of Kazeroon, Fars province. Iranian Journal of Forest and Poplar Research, v. 19, n. 2, p. 352-363, 2011. (In Persian). https://www.sid.ir/en/journal/ViewPaper.aspx?id=219305

HOSSEINI, A. Infestation of forest trees to the borer beetle and its relation to habitat conditions in the Persian oak (Quercus brantii) in llam Province. Iranian Journal of Forest and Range Protection Research, p. 53-66, 2012. (In persian). https://dx.doi.org/10.22092/ijfrpr.2011.106193

HOSSEINI, A. Effects of some of Persian oak tree and stand characteristics on crown dieback rate in oak forests of medium Zagros Journal of Zagros Forests Research, v. 1, n. 1, p. 37-50, 2014. (In persian). http://yujs.yu.ac.ir/jzfr/ article-1-22-en.html

HOSSEINI, A.; HOSSEINI, S. M.; CALDERON, J. C. L. Site factors and stand conditions associated with Persian oak decline in Zagros mountain forests. Forest systems, v. 26, n. 3, e014, 13pp, 2017. https://doi.org/10.5424/ fs/2017263-11298.

HOSSEINZADEH, J.; POURHASHEMI, M. An investigation on the relationship between crown indices and the severity of oak forests decline in Ilam. Iranian Journal of Forest, v. 7, n. 1, p. 57-66, 2015. (In persian). https://www.sid.ir/en/ Journal/ViewPaper.aspx?ID =462366

HWANG, C. L.; YOON, K. Multiple Attribute Decision Making: Methods and Applications, A State-of-the-Art Survey, Springer-Verlag. Berlin Heidelberg, New York 1981, 1981. 261p.

ILAM DEPARTMENT OF NATURAL RESOURCES AND WATERSHED MANAGEMENT REPORT. Report of Forest, Rangeland and Watershed Management Unit, Ilam. 2013. 273p.

JENKINS, M. A.; PALLARDY, S. G. The influence of drought on red oak group species growth and mortality in the Missouri Ozarks. Canadian Journal of Forest Research, v. 25, n. 7 , p. 1119-1127, 1995.

KABRICK, J. M.; DEY, D. C.; JENSEN, R. G.; WALLENDORF, M. The role of environmental factors in oak decline and mortality in the Ozark Highlands. Forest Ecology and Management, v. 255, n. (5-6), 1409-1417, 2008.

KARAMI, O.; FALLAH, A.; SHATAEI, S.; LATIFI, H. Investigation on the feasibility of mapping of oak forest dieback severity using Worldview-2 satellite data (case study: Ilam forests). Iranian Journal of Forest and Poplar Research, v. 25, n. 3, p. 452-462, 2017. (In persian). 10.22092/ijfpr.2017.112879

KEENAN, R. J:; REAMS, G. A.; ACHARD, F.: DE FREITAS, J. V: GRAINGER, A LINDQUIST, E. Dynamics of global forest area: Results from the FAO Global Forest Resources Assessment 2015. Forest Ecology and Management, n. 352, p. $9-20$.

$\mathrm{KOOH}$ SOLTANI, S.; ALESHEIKH, A. A.; Ghermezcheshmeh, B.; MEHRI, S. An evaluation of potential Oak decline Forest of the Zagros using GIS, RS, FAHP methods. Iranian Journal of Ecohydrology, v. 5, n. 2, p. 713-725, 2018. (In persian). http:10.22059/IJE.2018.225917.448

LINARES, J. C.; TAIQUI, L.; CAMARERO, J. J. Increasing drought sensitivity and decline of Atlas cedar (Cedrus atlantica) in the Moroccan Middle Atlas forests. Forests, v. 2, n. 3, p. 777-796, 2011.

MAHDAVI, A: MALEKI, A: BAZGIR, M. Soil properties and carbon sequestration in Persian oak (Quercus brantii var. persica) forests, Iran. Journal of Forest Science, n. 65, 247-255, 2019

MAHDAVI, A: MIRZAEI ZADEH, V: NIKNEZHAD, M: KARAMI, O. Assessment and prediction of oak trees decline using logistic regression model (Case study: Bivareh forest, Malekshahi-Ilam). Iranian Journal of Forest and Range Protection Research. v. 13, n. 1, p. 20-33, 2015. (Inpersian)

MARVIE-MOHADJER, M.R. Silviculture. Tehran, University of Tehran Press. 2012. $400 p$

MUHAMMADI, J.; BAGHERI, K.; ZANDI, K.; NADIPOOR, N. M. Spatial Analysis and Ranking of Towns of Khuzestan Province In Terms of Development of ICT 
Indicators Using TOPSIS and AHP Techniques. Journal of Civil Engineering and Urbanism, v. 5, n. 2, p. 69-76, 2015.

POURHASHEMI, M.; JAHANBAZI GOUGANI, H.; HOSSEINZADEH, J.; BORDBAR, S. K.; IRANMANESH, Y.; KHODAKARAMI, Y. The history of oak decline in Zagros forests. Journal of Iran Nature, v. 2, n. 1, p. 30-37, 2017. (In ersian).

SAATY, T. L. How to make a decision: the analytic hierarchy process. European journal of operational research, v. 48, n. 1, 9-26, 1990.

SPETITCH, M. A.; FAN, Z.; HE, H. S.; WANG, W. J.; CROSBY, M. C.; SHIFLEY S. R. Oak decline across the Ozark Highlands-from stand to landscape and regional scale processes. In: Proceedings of the 18th biennial southern silvicultural research conference. e-Gen. Tech. Rep. SRS-212. Asheville, NC: US Department of Agriculture, Forest Service, Southern Research Station. n 212, p. $78-83,2016$
WANG, W: PENG, C: KNEESHAW, D. D: LAROCQUE, G. R: LUO, Z Droughtinduced tree mortality: ecological consequences, causes, and modeling Environmental Reviews, v. 20, n. 2, 109-121, 2012

ZADEH, L. A. Fuzzy sets. Information and control. v. 1, n. 8(3), 338-53, 1965.

ZANDEBASIRI, M.; SOOSANI, J.; POURHASHEMI, M. Evaluation of the crisis severity in forests of Kohgiluye and Boyerahmad province (Case study: Tang-e Solak). Iranian Journal of Forest and Poplar Research, v. 24, n. 4 665-674, 2017. (In persian)

ZANDEBASIRI, M.; POURHASHEMI, M. The place of AHP method among Mult Criteria Decision Making methods in forest management. International Journa of Applied Operational Research-An Open Access Journal, v. 6, n. 2, 75-89, 2016 